\title{
Dispersal and gene flow in free-living marine nematodes
}

\author{
Sofie Derycke ${ }^{1,2^{*}}$, Thierry Backeljau ${ }^{3,4}$ and Tom Moens ${ }^{1}$
}

\begin{abstract}
Dispersal and gene flow determine connectivity among populations, and can be studied through population genetics and phylogeography. We here review the results of such a framework for free-living marine nematodes. Although field experiments have illustrated substantial dispersal in nematodes at ecological time scales, analysis of the genetic diversity illustrated the importance of priority effects, founder effects and genetic bottlenecks for population structuring between patches $<1 \mathrm{~km}$ apart. In contrast, only little genetic structuring was observed within an estuary $(<50 \mathrm{~km})$, indicating that these small scale fluctuations in genetic differentiation are stabilized over deeper time scales through extensive gene flow. Interestingly, nematode species with contrasting life histories (extreme colonizers vs persisters) or with different habitat preferences (algae vs sediment) show similar, low genetic structuring. Finally, historical events have shaped the genetic pattern of marine nematodes and show that gene flow is restricted at large geographical scales. We also discuss the presence of substantial cryptic diversity in marine nematodes, and end with highlighting future important steps to further unravel nematode evolution and diversity.
\end{abstract}

Keywords: Connectivity, Cryptic species, Dispersal, Gene flow, Life history, Marine nematodes, Population genetics, Phylogeography

\section{Review}

Marine nematodes are amongst the most abundant and diverse Metazoa in marine sediments [1,2]. Estimates of species diversity, including terrestrial and parasitic species, vary widely and range from $10^{5}$ [3] to $10^{8}$ [4]. This huge taxonomic diversity encompasses a wide variety of feeding strategies and life history characteristics, but has at the same time hampered ecological studies because species identification is difficult. Consequently, ecological studies on free-living nematodes typically pool species into functional groups based on different feeding strategies [5], tail shape [6], body size [7], life history [8], or a combination of several of these parameters [9]. Next to these ecological studies, considerable work has been done over the last decades to provide an evolutionary framework for the phylum Nematoda $[10,11]$, with a special focus on terrestrial [12], marine [13,14] or parasitic nematodes [15]. These studies show that convergent evolution is a frequent phenomenon for nematode morphology, feeding

\footnotetext{
* Correspondence: s.derycke@ugent.be

'Department of Biology, Marine Biology section, Ghent University, Krijgslaan 281, S8, 9000, Ghent, Belgium

${ }^{2}$ CeMoFE, Ghent University, K.L. Ledeganckstraat 35, 9000, Ghent, Belgium Full list of author information is available at the end of the article
}

strategy and habitat. In contrast, there are only few studies on the importance of micro-evolutionary processes (gene flow, genetic drift and selection) for nematode evolution, even for parasitic nematodes [16]. Defining the scales of connectivity among marine populations and identifying the barriers to dispersal and gene flow are however crucial to understand the ecological and evolutionary properties of populations and the dynamics and persistence of populations under environmental changes.

Gene flow describes the exchange of genetic information between populations through migration, whereas dispersal is defined as the movement of individuals from one genetic population to another [17]. Consequently, from a population genetics perspective and for species where individuals rather than eggs or propagules are the mechanism for dispersal, dispersal and gene flow are synonyms [18]. Both terms are used throughout this review. For the marine environment, barriers to gene flow are not always obvious, and factors influencing connectivity among marine populations are roughly divided into physical (e.g. ocean currents, habitat characteristics) and biological (e.g. predation, behaviour) [19]. Retention of organisms in their native area [20] or water currents
C Biomed Central

(c) 2013 Derycke et al.; licensee BioMed Central Ltd. This is an Open Access article distributed under the terms of the Creative Commons Attribution License (http://creativecommons.org/licenses/by/2.0), which permits unrestricted use, distribution, and reproduction in any medium, provided the original work is properly cited. 
[21] can strongly limit marine dispersal, which may lead to structured populations [22].

In what follows, we aim to provide a state of the art on dispersal and gene flow at ecological (i.e. one to a few generations) and evolutionary time scales (i.e. hundreds of thousands of generations), and the factors that may influence them (such as life history, habitat and historical events), for marine nematode populations. We also discuss the current knowledge on cryptic marine nematode diversity and end by identifying key questions for future population genetic studies of marine nematodes.

\section{Dispersal in free-living marine nematodes at ecological time scales}

Dispersal is one of the most important life history traits for species evolution and persistence. Dispersal allows organisms to escape unsuitable environmental conditions, avoid competition and increase their distribution range. Dispersal distance is generally correlated with the presence and duration of pelagic larval stages in the water column [23], but there are many exceptions [24], with dispersal being species, season and location specific. Free-living marine nematodes do not have planktonic or pelagic larvae, eggs are generally deposited in situ, and their body size is so small that active dispersal over large distances is likely to be limited. Nevertheless, nematodes are able to actively move in the sediment [25,26], while others can actively emerge into and swim in the water column [27]. Large-bodied nematodes of the family Oncholaimidae rapidly colonize carcasses of fish and macrofauna, probably at least in part by active swimming [28]. They, and other nematodes, may use a variety of chemical cues in their environment to direct their movement towards particular patches [29,30], although it is unclear over what distances such chemotaxis can occur. Some nematode species form non-feeding dauer larvae which are resistant to many environmental stresses [31,32] and which in some species are often found attached to other invertebrates [33]. Such vector associations are known for terrestrial species and may account for dispersal over considerable distances [34], but their role for dispersal of marine nematodes is less documented (a list of commensal marine nematodes in Crustacea is provided by Sudhaus [35]). Passive dispersal of marine nematodes can occur through the ballast water of ships [36], but probably more importantly, through hydrodynamic forces [37]. The presence of nematodes in the water column is largely determined by their vertical distribution and abundance in the sediment [38]. Different nematode genera can also show different vertical distributions in the water column [39] as well as differential abilities to settle back to the sediment [40]. Next to hydrodynamic forces, species-specific traits such as feeding ecology [41,42], behaviour [40], or body morphology
[42] influence dispersal ability of marine nematodes. Similar active dispersal abilities have been observed in the deep sea [43-45], but here nematodes are far less abundant in the water column than in shallow-water habitats. The complex interactions between habitat, hydrodynamics and species-specific traits lead to high variation in dispersal patterns through space and time $[41,46]$, which in turn may lead to a high degree of patchiness in nematode community composition $[45,47]$.

Only limited information is available on the effects of dispersal at ecological time scales on population genetic structure in free-living marine nematodes. Litoditis marina typically frequents decaying and standing macroalgae in the intertidal, which form a rather transient habitat with frequent local extinctions when algae are decomposed. In such temporal habitats, the ability to disperse enables them to survive the strong fluctuations in habitat availability. L. marina produces dauer larvae, and due to its high reproductive capacity and short generation time it is an efficient colonizer that can establish populations from one or a few gravid females. To investigate the effect of colonization dynamics of L. marina on neutral genetic variation within and among patches in close proximity $(\leq 1 \mathrm{~km})$ to each other, Derycke et al. [48] performed a field experiment in which the genetic diversity of L. marina on newly colonized algae was surveyed during one month at two contrasting sites in an intertidal salt marsh: in one site, defaunated algae were incubated amongst permanent algal stands that can act as a source population, while no algal stands were present in the second site [48]. Algal deposits near the permanent algal stands were more rapidly colonized, reached a fivefold higher density of nematodes and had a higher genetic diversity than algal deposits ca $1 \mathrm{~km}$ away from the source population (Figure 1). Nevertheless, L. marina colonized these distant patches within 10 days, showing that dispersal of this nematode at this scale is substantial. In these distant patches, mtDNA haplotypes that were rare in the source population of the permanent algal stands were abundant suggesting that founder effects and genetic bottlenecks structured these populations (Figure 1). Hence, dispersal at ecological time scales clearly influences the genetic variation within and between patches. Since these colonization dynamics are likely to be related to the ephemeral nature of the habitat and the high reproductive output of L. marina, knowledge on the biology and ecology of nematode species is crucial to correctly interpret population genetic data and make conclusions on gene flow and population connectivity.

\section{Dispersal in free-living marine nematodes at evolutionary time scales}

Dispersal in the marine environment can be studied by capture-recapture studies [20] or by determining geochemical 


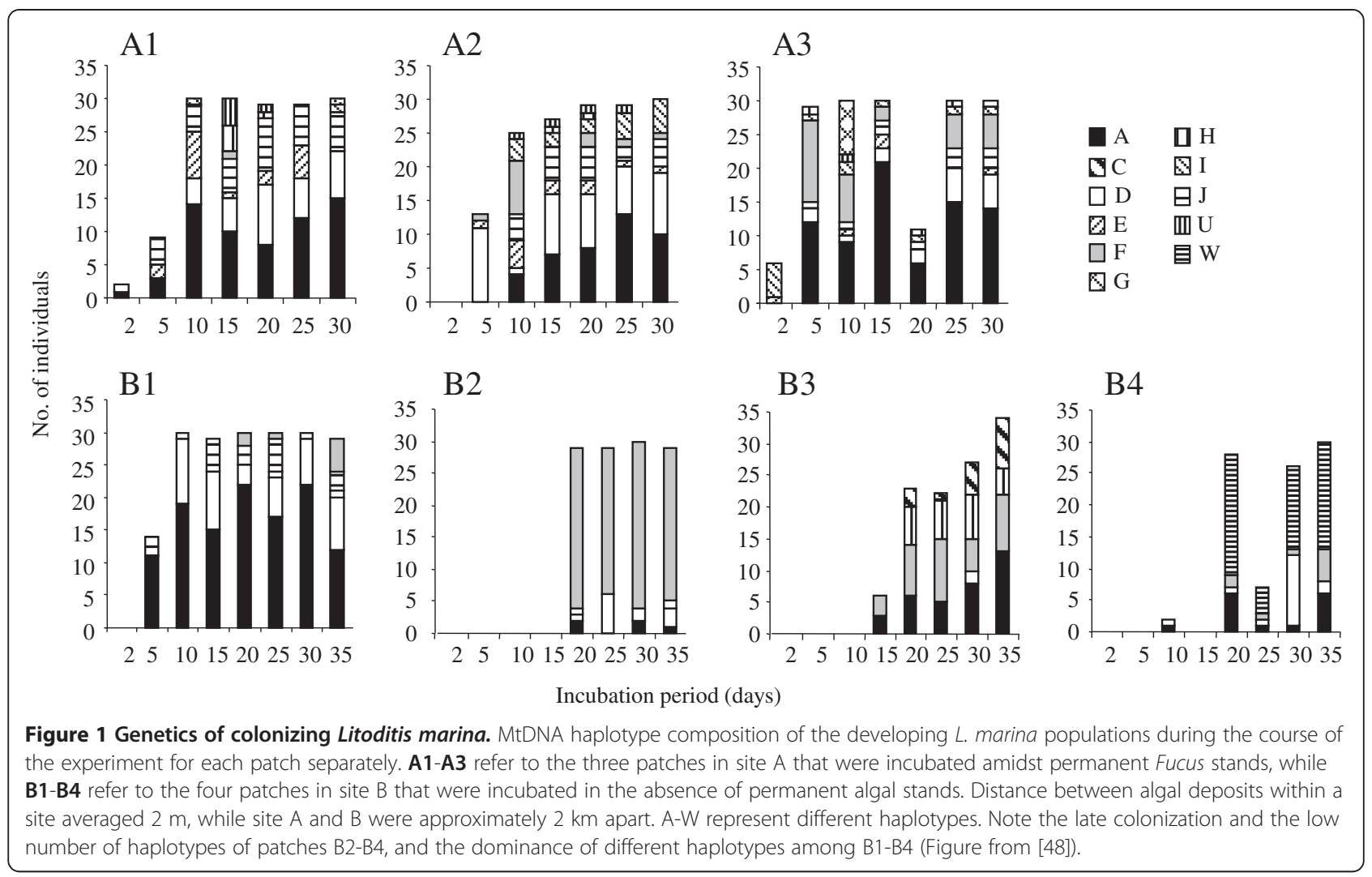

signatures in calcified structures (otoliths, shells), but these techniques cannot be applied to minute invertebrates lacking calcified structures. Therefore, dispersal has frequently been estimated indirectly from mathematical modeling or genetic data. The genetic structure is the result of the simultaneous action of evolutionary processes (gene flow, genetic drift and selection, Table 1) across thousands of generations, whereas field studies are restricted to ecological time scales spanning a limited number of generations.

Population genetic studies typically look at allele frequencies which are used to calculate $\mathrm{F}_{\mathrm{st}}$ values $[49,50]$

Table 1 Evolutionary processes leading to an increased or decreased genetic differentiation between natural populations of species

\begin{tabular}{lcc}
\hline Evolutionary process & $\begin{array}{c}\text { Genetic differentiation } \\
\text { between populations }\end{array}$ & $\begin{array}{c}\text { Genome } \\
\text { wide effects }\end{array}$ \\
\hline Mutation & Increases & No \\
Gene flow & Decreases & Yes \\
Genetic drift & Increases & Yes \\
Divergent selection & Increases & No \\
Balancing selection & Decreases & No \\
\hline
\end{tabular}

Gene flow and genetic drift act on the whole genome, while mutation and selection are acting on specific genomic regions. and related statistics, to infer to what degree genetic drift has driven groups of individuals towards fixation of alternative alleles. Therefore, these statistics are suitable to infer genetic structure caused by genetic drift, which is very often correlated with dispersal estimates [51], but processes other than gene flow may also be responsible for this structuring [52]. It is, for example, possible to have perfectly isolated populations between which $F_{\text {st }}$ can be comparatively low, simply because both populations are not fixed for alternative alleles [53-55]. Especially when highly variable markers such as microsatellite loci are used, additional statistics such as $\mathrm{D}$ or $\mathrm{F}_{\text {st }}^{\prime}$ can more adequately reveal genetic differentiation between populations $[56,57]$. Obviously, one should not blindly look at $\mathrm{F}_{\mathrm{st}}$ values to infer gene flow, but also explore the raw data (e.g. whether alleles are shared or not between populations). Next to these theoretical aspects, the genetic structure of marine species can be influenced by a variety of biological (e.g. life-history [58-60]) and physical (e.g. water currents [61]), as well as by the interplay between biological and physical factors [62]. In what follows, we review the effects of life history, habitat characteristics and long-term history on the population genetic structure of marine nematodes measured by $\Phi_{\text {st }}$ (which is similar to $\mathrm{F}_{\mathrm{st}}$, but also takes sequence divergence into account, whereas $F_{\text {st }}$ is based on allele frequencies only [63]). 


\section{The importance of life history for population genetic structure in marine nematodes}

Life histories are known for only a limited number of marine nematode species [e.g. 1,64-66]. Bongers et al. [31] categorized the expected colonizer characteristics of marine nematode genera based on ecological and biological information. This colonizer-persister (cp) scale varies between 1 (extreme colonizers with short generation times and high reproductive output) and 5 (extreme persisters with long generation times and few offspring). Nematode species with $\mathrm{cp}=1$ are expected to show little genetic structuring because of their ability to rapidly colonize new habitats, while species with $\mathrm{cp}=5$ are expected to show more pronounced genetic structuring. On the other hand, genetic structuring of marine species with substantial differences in life history and taxonomy can be very similar [67].

Litoditis marina and Halomonhystera disjuncta have very short generation times and a high reproductive output $[25,68]$, enabling them to rapidly colonize new habitats [48]. Both species are abundant on decomposing and standing macroalgae in the intertidal, and have a cp value of 1 [31] or 2 for $H$. disjuncta if the presence of a dauer stage is taken as a prerequisite for a cp-score of 1 [69]. Both morphospecies are actually complexes of cryptic species [70,71] and population genetic structure in the most abundant species of the L. marina species complex (PmI) within the Westerschelde estuary was low but significant $\left(\Phi_{\mathrm{st}}=0.075, \mathrm{p}<0.0001\right.$, data recalculated from [70], Figure 2). In view of the ephemeral habitat and strong colonization dynamics of L. marina [48], changes in the genetic diversity are likely to occur over time. When sampled in four consecutive seasons, $11 \%$ of the genetic variation within each of the five locations in the Westerschelde could be attributed to differences among seasons $\left(\Phi_{\mathrm{sc}}=0.11, \mathrm{p}<0.0001,[72]\right)$. This confirms that genetic composition of populations changes over time in L. marina [72]. Although a significant genetic differentiation was observed among populations within seasons $\left(\Phi_{\mathrm{sc}}=0.14, \mathrm{p}<0.0001\right)$, there was no significant differentiation among populations when the four seasons were pooled by locations $\left(\Phi_{\mathrm{ct}}=0.01, \mathrm{p}=0.262\right)$. Since $L$. marina populations are highly unstable over time, this result suggests that the genetic differences caused by extinction-colonization dynamics become unimportant or balance each other when several time points are taken into account. Similar patterns of genetic structure have been observed in the dominant species (GD3) of the Halomonhystera disjuncta species complex in the Westerschelde ([71], Figure 2). Four locations were sampled in two different seasons, and a low but significant genetic structuring was observed among locations within seasons $\left(\Phi_{\mathrm{sc}}=0.086, \mathrm{p}<0.001\right.$, recalculated data from [71]), and temporal differences in genetic differentiation were observed within locations $\left(\Phi_{\mathrm{sc}}=0.086\right.$, $\mathrm{p}<0.001$ ). Again, when the genetic data from the two seasons were pooled within locations, no significant spatial differentiation was observed within the Westerschelde estuary $\left(\Phi_{\mathrm{ct}}=-0.0042, \quad \mathrm{p}=0.48\right)$. Although colonization-extinction dynamics can lead to genetic structuring at small geographical scales, such effects are no longer observed at time scales covering several generations.

If life-history characteristics are important in determining the genetic structure of nematode populations, pronounced differences in genetic structure would be

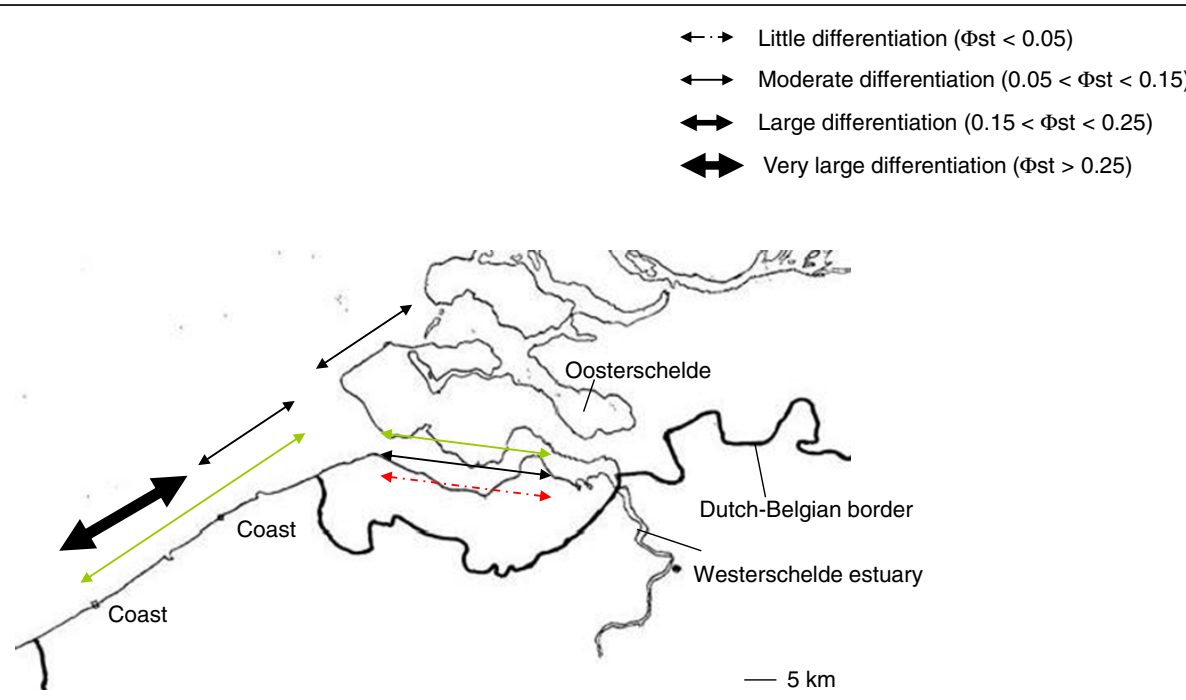

Figure 2 Genetic structuring in marine nematodes at small geographic scale $(<100 \mathrm{~km})$. The sampling area encompasses the Westerschelde estuary and the Oosterschelde in The Netherlands, and two Belgian coastal locations. The strength of differentiation is based on [53]. Black arrows: Litoditis marina; Green arrows: Halomonhystera disjuncta; Red arrow: Bathylaimus assimilis. 
expected in nematode species with a very long generation time and low number of offspring, because they have much smaller chance of colonizing new habitats than species with short generation times and high reproductive output. The nematode Thoracostoma trachygaster lives in holdfasts of kelp along the Californian coast [73], and the genus Thoracostoma has a cp value of 5 [31]. Although passive dispersal can still be significant in T. trachygaster because of its association with algal holdfasts, intuitively its very long generation time (probably only one or two generations per year) and few offspring would render successful establishment in new habitats less likely compared to L. marina and $H$. disjuncta. To exclude effects of well known biogeographic barriers, such as Point Conception and the Los Angeles Region, we investigated the genetic structure of $T$. trachygaster using populations that were continuously distributed along the coast with exclusion of these two barriers, and at a geographical scale of less than $100 \mathrm{~km}$, to be comparable with the geographic scale of the sampling in the Westerschelde (data recalculated from [74]). When taking into account mtDNA allele frequencies and mutations, no genetic structuring was observed within the southern Californian Bight $\left(\Phi_{\mathrm{st}}=0.035, \mathrm{p}=0.16\right.$; Figure 3$)$. This may suggest that K-strategists do not necessarily have a strong genetic structure. Similar results have been observed for K-strategists in other phyla [75]. At fine geographical scales $(<300 \mathrm{~km})$, shared environmental drivers such as water currents or habitat characteristics may cause similar genetic patterns in species with quite different life histories [67].

\section{The importance of habitat characteristics for population genetic structure in marine nematodes}

Bathylaimus assimilis is an endobenthic nematode species that in contrast to L. marina, $H$. disjuncta and
T. trachygaster, is not associated with macroalgae. Dispersal through rafting is therefore unlikely for $B$. assimilis. Moreover, several endobenthic nematode species show vertical migration in the sediment [76], and possibly avoid in this way erosion and resuspension in the water column. Therefore the passive dispersal potential of $B$. assimilis is expected to be lower than that of $L$. marina and $H$. disjuncta. Because $B$. assimilis is a less efficient colonizer than L. marina and $H$. disjuncta, and because it has an endobenthic life style, its population genetic subdivision in the Westerschelde is expected to be more pronounced than that of L. marina and H. disjuncta. Yet, a COI sequence analysis of 173 specimens from four locations in the Westerschelde suggested only a weak, but still significant structuring $\left(\Phi_{\mathrm{st}}=0.044, \mathrm{p}<0.0001\right.$; Figure 2$)$. Although $B$. assimilis lives in the sediment, it can occasionally be observed in the water column [42], increasing its potential for passive dispersal. In conclusion, at small geographical scales of $50 \mathrm{~km}$, population genetic structuring does not seem to depend on whether a nematode is an epiphytic or endobenthic species (but see section on suggestions for future research).

Although gene flow in marine nematodes seems to be quite substantial at scales of $50 \mathrm{~km}$, adding two nearby coastal locations to the Westerschelde data generated $\Phi_{\text {st }}$ values that were an order of magnitude larger than the values obtained for the Westerschelde populations alone (Litoditis marina PmI: $\Phi_{\mathrm{st}}=0.12-0.28, \mathrm{p}<0.0001$, data recalculated from [72]; Halomonhystera disjuncta GD3: $\Phi_{\mathrm{st}}=0.11-0.13, \mathrm{p}<0.0001$ [71]; Figure 2). The stepping stone model assumes that dispersal declines with geographic distance, resulting in an increase in genetic dissimilarity between populations that are more distant from each other [77]. Such isolation by distance (IBD) is supported when there is a positive correlation

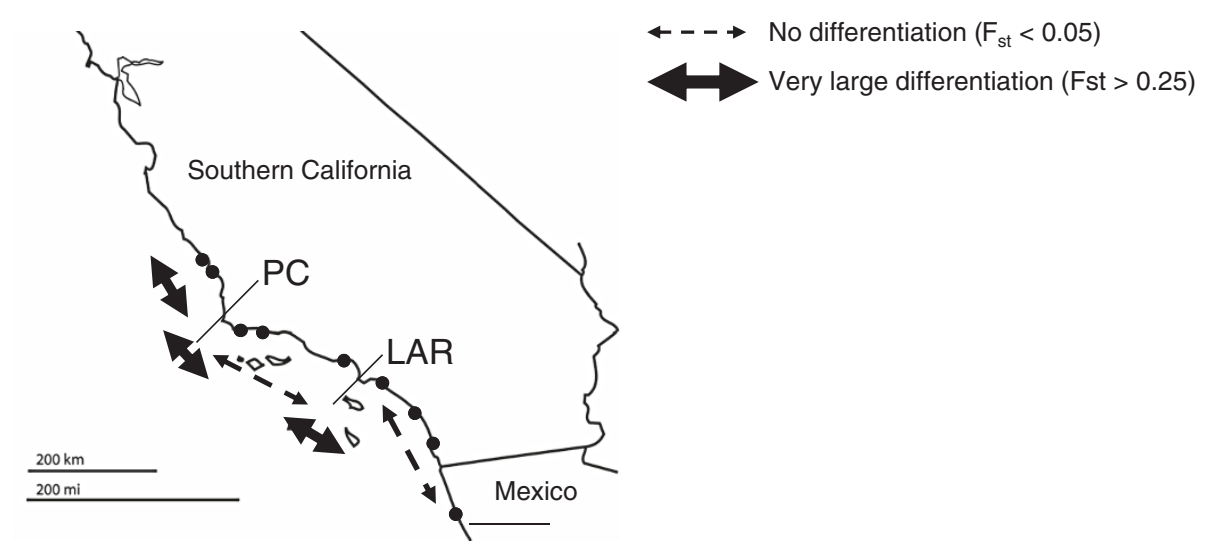

Figure 3 Genetic structuring in Thoracostoma trachygaster at large geographic scale $(>\mathbf{5 0 0} \mathbf{k m})$. The study area is situated along the Californian coast, and includes two biogeographic barriers: Point Conception (PC) and the Los Angeles Region (LAR). $F_{\text {st }}$ values are based on those reported in [74]. 
between genetic and geographic distance [78]. Since there are no obvious barriers to gene flow between the Westerschelde and coastal locations, the more pronounced genetic structuring observed may be caused by geographic distance. However, no significant correlation was observed between genetic and geographic distances for the most widespread species of the $H$. disjuncta complex [71]. For L. marina, IBD was found in only one season [72]. In several cases, significant pairwise genetic differentiation was observed between close populations, while no significant differentiation was observed between distant populations. This 'chaotic genetic patchiness' pattern is quite common for the marine environment [67], and can be explained by the nonlinear movement of organisms due to turbulent and nonlinear water currents. Taking into account water currents [61] and other environmental data [67] is therefore essential to interpret population genetic data and connectivity in the marine environment. Next to the estuarine and coastal locations, L. marina was also sampled in the Oosterschelde, a semi-estuarine environment that is partly closed from the sea by a storm surge barrier, which may provide a higher level of isolation. The habitat type (coastal, estuarine or semi-estuarine) had an impact on the genetic patterns observed within L. marina (PmI): $11.15 \%$ of the variation could be explained by habitat type $\left(\Phi_{\mathrm{ct}}=0.11\right.$, $\mathrm{p}<0.0001$ ), but a comparable amount of variation (13.09\%) was observed by differences between populations within each habitat type $\left(\Phi_{\mathrm{sc}}=0.14, \mathrm{p}<0.0001\right.$, data recalculated from [72]. As shown for marine invertebrates with larval dispersal stages $[61,67,79,80]$, these results indicate that water currents and ecological characteristics of the habitat may be equally important drivers for the genetic structure of marine nematodes than geographic distance or life history characteristics alone.

\section{The importance of geological history for population genetic structure in marine nematodes}

Quite a number of marine nematode species show a widespread geographic distribution [81-83], indicating that long distance dispersal can also occur. Next to life history and habitat, historical events such as land mass drift, sea level rises and glacial cycles have influenced the current distribution and population genetic structuring of many marine invertebrates [84]. For the North Atlantic, the quaternary glacial cycles have had dramatic impacts on species distributions, with many species being forced to migrate to the south during glacial periods, followed by recolonization of the northern areas during interglacial periods. These distributional changes have left a genetic imprint, with northern populations being genetically less diverse, and southern populations being genetically richer [85]. Phylogeographical studies in the marine environment have also pinpointed refugial areas e.g. [84], recolonization routes and genetic breaks in a variety of marine organisms. Such genetic breaks can ultimately lead to speciation.

All species of the $L$. marina species complex sampled on a pan European scale showed strong genetic structuring (Table three in [81]), demonstrating that gene flow at larger geographical scales is restricted. When integrating historical processes that have shaped the distribution of temperate species in the North Atlantic with the observed genetic patterns in the L. marina complex, the evolutionary history of the species complex becomes visible. For the two most widespread species of the complex (PmI, PmII), a genetic break along the British Isles was observed, and two possible postglacial recolonization routes of northern areas were suggested, one around the British Isles, and one through the English Channel [81] (Figure 4). The Southern Bight of the North Sea acted as a secondary contact zone between these routes. These results illustrate that the quaternary ice ages have influenced the genetic pattern of marine nematodes. Moreover, several population pairwise $\Phi_{\text {st }}$ values were non-significant, despite populations being separated by obvious geographical barriers (e.g. Baltic and Mediterranean). This illustrates again the chaotic genetic patchiness and suggests that additional ecological factors are influencing the genetic structure of marine nematodes.

Next to glacial cycles, well known biogeographical barriers often coincide with genetic breaks between populations on either side of the barrier [86,87]. Thoracostoma trachygaster was sampled along the Californian coast [74], where Point Conception (PC) [88] and Los Angeles Region (LAR) [59] are well-known biogeographic barriers. PC is associated with genetic breaks in high dispersal species, while LAR coincides with genetic breaks in low dispersal species $[59,89]$. T. trachygaster showed a strong genetic structuring along the Californian coastline $\left(\Phi_{\mathrm{st}}=0.28, \mathrm{p}<0.001\right)$, with a significant amount of this variation being explained by differences between populations north and south of PC and, within the Southern Californian Bight, between populations north and south of LAR (Figure 3, [74]).

Clearly, these studies illustrate that historical processes and biogeographic barriers have strongly affected the genetic variation of marine nematode populations. Furthermore, since these historical events are still detected in the present day genetic composition of marine nematodes, gene flow in marine nematodes must be restricted at such large geographical scales.

\section{'Collateral' outcomes of population genetic studies: cryptic species}

Population genetic and phylogeographic studies typically investigate a large number of specimens from several 


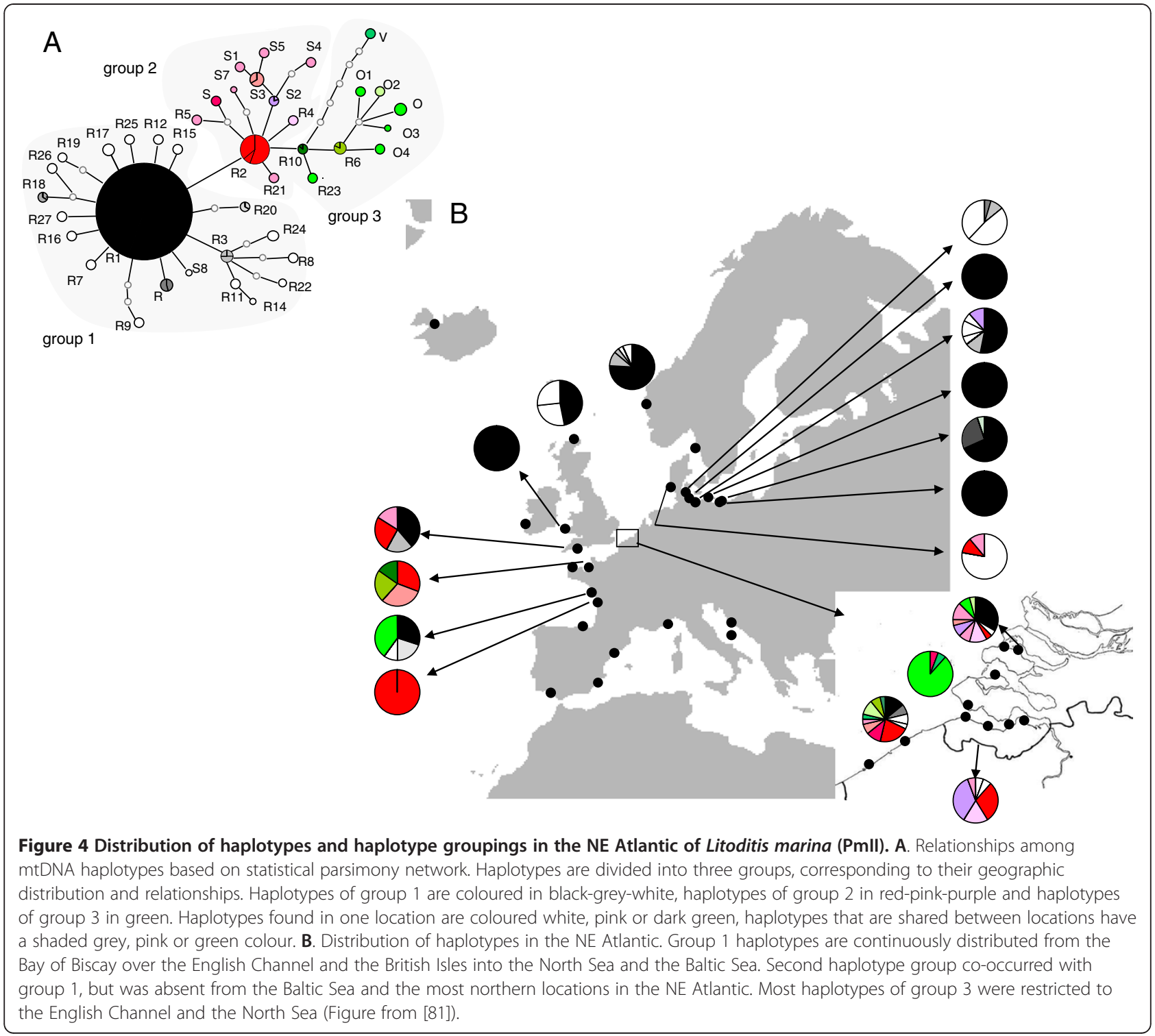

populations across a species' geographic range. The majority of known species are however based on descriptions of small numbers of specimens from single or just few localities [90], thereby ignoring the extent of natural variation. Furthermore, the widespread distribution of nematodes is in contrast with their limited dispersal abilities at large geographic scales. This so-called "meiofauna-paradox" [91] may be explained by the presence of cryptic species within what were previously thought to be generalist species [92]. The term "cryptic species" refers to taxa that are morphologically similar, but that belong to different gene pools. Such cryptic diversity occurs in a variety of metazoan taxa and biogeographical regions [93], and may be particularly abundant in the marine environment [94]. This may be because many marine species rely on chemical cues for mate choice and gamete recognition [22,95,96], as well as for ecological interactions [97]. Chemotaxis is used by freeliving nematodes to detect food sources $[98,99]$ and parasitic nematodes are able to detect conspecifics in hosts [100]. It is therefore likely that taste and smell are also important for mate recognition in marine nematodes, but no data are currently available to confirm this.

Morphological similarity can be the result of strong divergent selection on non-visual mating signals [101], or, alternatively, morphological stasis may be the result of ecological constraints, where adaptive evolution favors similar phenotypes over and over again [102]. Whatever the speciation process, leaving cryptic diversity unrecognized will bias the interpretation of biogeographical and ecological patterns [101]. 
Nematode morphology is generally thought to be conserved, leading to speculations on the presence of substantial cryptic diversity in this taxon [101]. However, in a meta-analysis of animal cryptic diversity, cryptic species were not more common in nematodes than in other metazoan taxa [93]. Our population and phylogeographic studies of marine nematodes have revealed the presence of cryptic diversity in various degrees: 10 cryptic species were found in Litoditis marina [103], five in Halomonhystera disjuncta [71] and three in Thoracostoma trachygaster [74,104]. These different numbers of cryptic species may be explained by different sampling efforts, with L. marina having been sampled most intensively during four seasons [72] and at a paneuropean scale [81]. When looking at just one season and at the scale of a single estuary (the Westerschelde), two to three cryptic species were found in L. marina and $H$. disjuncta. These numbers are quite high considering a geographical scale of less than $50 \mathrm{~km}$, and one might wonder whether this is typical for fast-growing, opportunistic species with rapid reproduction and high numbers of offspring. Preliminary results for the endobenthic monhysterid Theristus acer in the Westerschelde show three deeply divergent clades in the COI gene (Derycke, unpublished data). Assuming that these lineages represent cryptic species, the presence of cryptic species seems therefore not to be correlated with life history traits. Instead, the prevalence of cryptic diversity in species with different life histories and from different areas suggests that it is a common phenomenon for marine nematodes. Nevertheless, we did not find any indications of cryptic species in the endobenthic enoplid Bathylaimus assimilis within the Westerschelde (Derycke, unpublished data), so caution is needed when making such generalizations based on the limited data available.

Species in species complexes were delimited using the phylogenetic species concept with reciprocal monophyly of nuclear and mitochondrial gene trees. For nematodes, this approach is well-suited [105]. Subsequent detailed morphological studies have shown that the cryptic taxa in these complexes do differ in morphometric characteristics $[103,104,106]$. However, such differences in morphometry may at least partly be related to environmental conditions such as food availability and temperature, and are thus less suited to delineate or describe species. Detailed morphological studies may however also find diagnostic characters between cryptic species [104,107]. In this way, genetic studies can pinpoint groups that deserve closer morphological study, and can greatly enhance taxonomic studies in small organisms lacking easily observable morphological characters.

Despite the substantial increase of the discovery of cryptic species over the last decade $[101,108]$, only little autecological information is available for cryptic species. For estuarine invertebrates, cryptic species can, for instance, show different tolerances to salinity which can explain their partly overlapping distribution ranges [92,109]. The field distribution of the cryptic nematode species shows that several species tend to co-occur [70,71,74,81], and that temporal fluctuations in species abundances are pronounced [71,72]. Furthermore, at a paneuropean geographical scale, several cryptic species seem to have restricted distributions [81], which may point to differential ecological tolerances/preferences for abiotic factors. Laboratory experiments have shown that two of the four cryptic L. marina species (PmI and PmIII) from the Westerschelde show a faster population development at a salinity of $15 \mathrm{psu}$ than at a salinity of $25 \mathrm{psu}$ [110]. Furthermore, when the four species of L. marina were combined in a multi species treatment, interspecific interactions reduced the population development of species PmII and even led to the total extinction of species PmIV. These interspecific interactions were also clearly affected by salinity, suggesting that fluctuations in abiotic factors may at least in part drive the coexistence of cryptic nematode species at local scales [110].

\section{Where to go from here? \\ Nematode population genetics with multiple markers}

The population genetic data of marine nematodes are exclusively based on COI, the usefulness of which has been well-documented [87,111]. Although mtDNA is usually treated as if it evolves in a neutral manner, recent studies suggest that selection may also be acting on the mtDNA [112]. Therefore, using independently evolving loci will enhance the correct interpretation of the processes responsible for the observed genetic patterns. Microsatellite loci (see e.g. [113,114] for a background) have become tremendously popular for population genetic studies because of their high intraspecific variability, which allows investigation of contemporary gene flow at small geographical scales. Yet, although microsatellite loci have been used in population genetic studies of parasitic nematodes [115-117] and in the model nematode Caenorhabditis elegans $[118,119]$, no such data are currently available for marine nematodes.

\section{Understanding the role of ecology in nematode population genetics}

Life history, morphology, behavior and habitat-associated traits all contribute to dispersal ability, but hitherto their relative importance for the genetic structure in marine nematodes remains largely unknown. Comparing the genetic structure between several species differing in one of these traits can contribute to unravel the relative importance of these traits for micro-evolutionary processes [51]. For instance, by including additional nematode species isolated from the same geographic area but with life histories that differ from that of efficient colonizers such as 
L. marina and $H$. disjuncta, the effects of life history on population structure and nematode evolution can be explored. Similarly, including species with different habitat preferences should highlight habitat related effects on genetic structure. Since both $L$. marina and $H$. disjuncta occur on macroalgae, they are likely to have substantial passive dispersal capacity, and their dispersal ability may thus be much larger than that of typically endobenthic nematode species. Although for the time being this is not confirmed by our data on Bathylaimus assimilis, one would expect that if an endobenthic life style restricts dispersal in marine nematodes, then one should find higher $\Phi_{\text {st }}$ values in these species.

\section{Unravelling the importance of environmental drivers for nematode dispersal through sea scape genetics}

Next to species-specific ecological characteristics, dispersal in marine nematodes may be driven by environmental parameters. The genetic structuring in marine nematodes so far does not seem to correlate with geographic distance, but instead shows chaotic genetic patchiness: population pairwise $\mathrm{F}_{\mathrm{st}}$ values are often significant between populations in close proximity, while they are not for populations that are further apart. This pattern may well be caused by the hydrodynamic currents in the study area, as well as by other ecological factors. Coupling hydrodynamic [61,120] and other environmental data [67] with genetic structuring, the so-called sea scape genetics approach [121], can help to sort out the causes of spatial patterns in marine population genetics.

\section{Investigating the importance of selection for population differentiation in nematodes}

Next to the analysis of neutral genetic variation, understanding the importance of selection on genetic structuring is essential for predicting how populations will respond to changing environments and to understand evolutionary diversification. Neutral loci across the genome will be similarly affected by demography and the evolutionary history of populations, while loci under selection will often behave differently and therefore reveal 'outlier' patterns of variation [122]. Next generation sequencing (NGS) makes it more feasible than ever to identify genes underpinning adaptive evolution in nonmodel organisms. Single Nucleotide Polymorphisms (SNP's) are very common and distributed across the genome, and can be screened for many individuals from different populations through Restriction site Associated DNA sequencing (RADSeq) [123,124]. RADseq tags digested DNA from a large number of individuals, which are then pooled and sequenced using Illumina. The resulting sequence reads can be analysed without a reference genome by aggregating identical reads into unique sequences. Subsequently, unique sequences with only a small number of mismatches are clustered, and SNP's can be scored between alleles at the same locus [125]. In this way, RADSeq generates thousands of genetic markers in a large number of specimens at a reasonable cost [125]. By choosing populations living in e.g. different temperature or salinity conditions, which are amongst the most important forces for local adaptation in marine invertebrates [126], and comparing the genetic differentiation between these populations at different genomic regions, it becomes possible to pinpoint those genomic regions that are under selection.

\section{Investigating the influence of genome evolution on population genetic patterns in marine nematodes}

The advance in sequencing technology has generated an unprecedented amount of genome and transcriptome data from, mainly parasitic, nematode species $[127,128]$. Horizontal gene transfer is a common phenomenon in plant parasitic nematodes $[129,130]$, but has not been reported in free-living nematodes [130]. Comparative genomics between the free-living Caenorhabditis elegans and $C$. briggsae have revealed extensive intrachromosomal rearrangements, but remarkable conservation of chromosome organization and synteny [131]. Comparison of mitochondrial genomes across parasitic nematode species has revealed a large number of gene rearrangements, large duplications, and the use of both DNA strands to encode genes [132]. Furthermore, the presence of minicircular [133] and multipartite mitochondrial genomes has been documented [134]. The effect of these genomic differences on population genetic patterns and nematode dispersal is unknown. Clearly, genome sequences of marine nematodes are urgently needed to investigate the prevalence of these phenomena in marine nematodes and their effect on interpreting population genetic patterns.

\section{Conclusion}

Experimental field studies have demonstrated that dispersal of marine nematodes at ecological time scales (i.e. $<10$ generations) is substantial in the estuarine environment. The use of genetic data revealed that colonization dynamics strongly affect the genetic composition of local patches, with founder effects and bottlenecks causing strong differentiation among nearby patches. At deeper time scales, these genetic differences seem to disappear and populations become homogeneous. Consequently, gene flow in the marine nematodes analysed so far is substantial at geographical scales of $50 \mathrm{~km}$, but is strongly restricted at larger geographical scales (several 100's of kilometers). This scale is tentative, and depends on a variety of environmental factors. Our data suggest that life history (short generation time and high reproductive output vs. long generation time and low reproductive output) 
and habitat preference (algae vs. sediment) may be less important drivers for dispersal in marine nematodes, but additional analyses of the genetic structure in other nematode species are required to confirm these observations.

\section{Competing interests}

The authors declare that they have no competing interests.

\section{Authors' contributions}

SD conceived and wrote the manuscript, and analysed the data. TB and TM critically reviewed the manuscript and improved its intellectual content. All authors read and approved the final manuscript.

\section{Acknowledgements}

S.D. acknowledges a postdoctoral fellowship from the Flemish Fund for Scientific Research (F.W.O.). This research was financially supported by the F. W.O through the project 3G040407 and by Ghent University through the BOF project B/07778/02. Annelien Rigaux and Mylene Collin are acknowledged for their help in the molecular analyses.

\section{Author details}

'Department of Biology, Marine Biology section, Ghent University, Krijgslaan 281, S8, 9000, Ghent, Belgium. ${ }^{2} \mathrm{CeMoFE}$, Ghent University, K.L.

Ledeganckstraat 35, 9000, Ghent, Belgium. ${ }^{3}$ Royal Belgian Institute of Natural Sciences (Joint Experimental Molecular Unit), Vautierstraat 29, 1000, Brussels, Belgium. ${ }^{4}$ Department of Biology, Evolutionary Biology Group, University of Antwerp, Groenenborgerlaan 171, 2020, Antwerp, Belgium.

Received: 3 September 2012 Accepted: 21 January 2013

Published: 28 January 2013

\section{References}

1. Heip C, Vincx M, Vranken G: The ecology of marine nematodes. Oceanography and Marine Biology: an annual review 1985, 23:399-489.

2. Lambshead PJD: Marine nematode biodiversity. In Nematology: Advances and Perspectives Vol 1: Nematode Morphology, Physiology and Ecology. Edited by Chen ZX, SCDD. UK: CABI Publishing; 2004:436-467.

3. Coomans A: Nematode systematics: past, present and future. Nematology 2000, 2:3-7.

4. Lambshead PJD: Recent developments in marine benthic biodiveristy research. Oceanis 1993, 19:5-24.

5. Moens T, Vincx M: Observations on the feeding ecology of estuarine nematodes. J Mar Biol Assoc UK 1997, 77:211-227.

6. Thistle D, Lambshead PJD, Sherman KM: Nematode tail-shape groups respond to environmental differences in the deep sea. Vie et Milieu 1995, 45:107-115.

7. Vanaverbeke J, Soetaert K, Vincx M: Changes in morphometric characteristics of nematode communities during a spring phytoplankton bloom deposition. Mar Ecol Prog Ser 2004, 273:139-146.

8. Bongers T, Bongers M: Functional diversity of nematodes. Appl Soil Ecol 1998, 10:239-251.

9. Schratzberger M, Warr K, Rogers SI: Functional diversity of nematode communities in the southwestern North Sea. Mar Environ Res 2007, 63:368-389.

10. Blaxter ML, De Ley P, Garey JR, Liu LX, Scheldeman P, Vierstraete A, Vanfleteren $J R$, Mackey LY, Dorris M, Frisse LM, et al: A molecular evolutionary framework for the phylum Nematoda. Nature 1998, 392:71-75.

11. Holterman $M$, van der Wurff $A$, van den Elsen $S$, van Megen $H$, Bongers $T$, Holovachov O, Bakker J, Helder J: Phylum-wide analysis of SSU rDNA reveals deep phylogenetic relationships among nematodes and accelerated evolution toward crown clades. Mol Biol Evol 2006, 23:1792-1800.

12. Holterman M, Rybarczyk K, Van den Elsen S, Van Megen H, Mooyman P, Santiago RP, Bongers T, Bakker J, Helder J: A ribosomal DNA-based framework for the detection and quantification of stress-sensitive nematode families in terrestrial habitats. Mol Ecol Resour 2008, 8:23-34.

13. Meldal BHM, Debenham NJ, De Ley P, De Ley IT, Vanfleteren JR, Vierstraete AR, Bert W, Borgonie G, Moens T, Tyler PA, et al: An improved molecular phylogeny of the Nematoda with special emphasis on marine taxa. $\mathrm{Mol}$ Phylogenet Evol 2007, 42:622-636.
14. Bik HM, Lambshead PJD, Thomas WK, Lunt DH: Moving towards a complete molecular framework of the Nematoda: a focus on the Enoplida and early-branching clades. BMC Evol Biol 2010, 10:14.

15. Nadler SA, Carreno RA, Mejia-Madrid H, Ullberg J, Pagan C, Houston R, Hugot JP: Molecular phylogeny of clade III nematodes reveals multiple origins of tissue parasitism. Parasitology 2007, 134:1421-1442.

16. Plantard O, Porte C: Isolation and characterization of microsatellite loci in the sugar beet cyst nematode Heterodera schachtii. Mol Ecol Notes 2003, 3:139-141.

17. Allendorf FW, Luikart G: Conservation and the genetics of populations. Oxford, UK: Blackwell Publishing; 2007.

18. Slatkin M: Gene flow in natural populations. Annu Rev Ecol Syst 1985, 16:393-430.

19. Hohenlohe PA: Limits to gene flow in marine animals with planktonic larvae: models of Littorina species around Point Conception, California. Biol J Linn Soc 2004, 82:169-187.

20. Jones GP, Planes S, Thorrold SR: Coral reef fish larvae settle close to home. Curr Biol 2005, 15:1314-1318.

21. Ayata SD, Lazure $P$, Thiebaut E: How does the connectivity between populations mediate range limits of marine invertebrates? A case study of larval dispersal between the Bay of Biscay and the English Channel (North-East Atlantic). Prog Oceanogr 2011, 87:18-36.

22. Palumbi SR: Genetic divergence, reproductive isolation, and marine speciation. Annu Rev Ecol Syst 1994, 25:547-572.

23. Siegel DA, Kinlan BP, Gaylord B, Gaines SD: Lagrangian descriptions of marine larval dispersion. Mar Ecol Prog Ser 2003, 260:83-96.

24. Shanks AL: Pelagic larval duration and dispersal distance revisited. Biol Bull 2009, 216:373-385.

25. Jacobs LJ: Monografische studie van de Monhysteridae de Man, 1876 (Nematoda). PhD dissertation: Ghent University, Biology Department; 1988.

26. Schratzberger M, Whomersley P, Warr K, Bolam SG, Rees HL: Colonisation of various types of sediment by estuarine nematodes via lateral infaunal migration: a laboratory study. Mar Bio/ 2004, 145:69-78.

27. Jensen P: Phyto-chemical sensitivity and swimming behavior of the freeliving marine nematode Chromadorita tenuis. Mar Ecol Prog Ser 1981, 4:203-206.

28. Lorenzen S, Prein M, Valentin C: Mass aggregations of the free-living marine nematode Pontonema vulgare (Oncholaimidae) in organically polluted fjords. Mar Ecol Prog Ser 1987, 37:27-34.

29. Huettel RN: Chemical communicators in nematodes. J Nematol 1986, 18:3-8.

30. Riemann F, Ernst W, Ernst R: Acetate uptake from ambient water by the free-living marine nematode Adoncholaimus thalassophygas. Mar Biol 1990, 104:453-457.

31. Bongers T, Alkemade R, Yeates GW: Interpretation of disturbance-induced maturity decrease in marine nematode assemblages by means of the maturity index. Mar Ecol Prog Ser 1991, 76:135-142.

32. Mayer MG, Sommer RJ: Natural variation in Pristionchus pacificus dauer formation reveals cross-preference rather than self-preference of nematode dauer pheromones. Proc R Soc B-Biol Sci 2011, 278:2784-2790.

33. Poinar GO (Ed): The natural history of nematodes. New Jersey, USA: Prentice Hall; 1983

34. Kuhne R: Relations between free-living nematodes and dung-burying Geotrupes spp (Coleoptera: Geotrupini). Fundam Appl Nematol 1996, 19:263-271.

35. Sudhaus W: Nematoden (insbesondere Rhabditiden) des Strandanwurfs und ihre Beziehungen zu Krebsen. Faunistisch Okologische Mitteilungen 1974, 4:365-400

36. Radziejewska T, Gruszka P, Rokicka-Praxmajer J: A home away from home: a meiobenthic assemblage in a ship's ballast water tank sediment. Oceanologia 2006, 48:259-265.

37. Palmer MA: Dispersal of marine meiofauna - a review and conceptualmodel explaining passive transport and active emergence with implications for recruitment. Mar Ecol Prog Ser 1988, 48:81-91.

38. Eskin RA, Palmer MA: Suspension of marine nematodes in a turbulent tidal creek - Species patterns. Biol Bull 1985, 169:615-623.

39. Boeckner MJ, Sharma J, Proctor HC: Revisiting the meiofauna paradox: dispersal and colonization of nematodes and other meiofaunal organisms in low- and high-energy environments. Hydrobiologia 2009, 624:91-106.

40. Ullberg J, Olafsson E: Free-living marine nematodes actively choose habitat when descending from the water column. Mar Ecol Prog Ser 2003, 260:141-149. 
41. Commito JA, Tita G: Differential dispersal rates in an intertidal meiofauna assemblage. J Exp Mar Biol Ecol 2002, 268:237-256.

42. Thomas MC, Lana PC: A new look into the small-scale dispersal of freeliving marine nematodes. Zoologia 2011, 28:449-456.

43. Guilini K, Soltwedel T, van Oevelen D, Vanreusel A: Deep-sea nematodes actively colonise sediments, irrespective of the presence of a pulse of organic matter: results from an in-situ experiment. PLoS One 2011, 6:e18912.

44. Guidi-Guilvard LD, Thistle D, Khripounoff A, Gasparini S: Dynamics of benthic copepods and other meiofauna in the benthic boundary layer of the deep NW Mediterranean Sea. Mar Ecol Prog Ser 2009, 396:181-195.

45. Gallucci F, Moens T, Vanreusel A, Fonseca G: Active colonisation of disturbed sediments by deep-sea nematodes: evidence for the patch mosaic model. Mar Ecol Prog Ser 2008, 367:173-183.

46. Bostrom C, Tornroos A, Bonsdorff E: Invertebrate dispersal and habitat heterogeneity: expression of biological traits in a seagrass landscape. J Exp Mar Biol Ecol 2009, 390:106-117.

47. Gingold R, Ibarra-Obando SE, Rocha-Olivares A: Spatial aggregation patterns of free-living marine nematodes in contrasting sandy beach micro-habitats. J Mar Biol Assoc UK 2011, 91:615-622.

48. Derycke S, Van Vynckt R, Vanoverbeke J, Vincx M, Moens T: Colonization patterns of Nematoda on decomposing algae in the estuarine environment: community assembly and genetic structure of the dominant species Pellioditis marina. Limnol Oceanogr 2007, 52:992-1001.

49. Wright S: Systems of mating. Genetics 1921, 6:111-178.

50. Wright S: The genetical structure of populations. Ann Eugen 1951, 15:323-354.

51. Bohonak AJ: Dispersal, gene flow, and population structure. Q Rev Biol 1999, 74:21-45.

52. Whitlock MC, McCauley DE: Indirect measures of gene flow and migration: $F_{S T}$ not equal 1/(4Nm + 1). Heredity 1999, 82:117-125.

53. Wright S: Evolution and the genetics of populations. Chicago: University of Chicago Press; 1978

54. Van den Broeck H, Breugelmans K, Hans DW, Backeljau T: Completely disjunct mitochondrial DNA haplotype distribution without a phylogeographic break in a planktonic developing gastropod. Mar Biol 2008, 153:421-429.

55. Raybould AF, Clarke RT, Bond JM, Welters RE, Gliddon CJ: Inferring patterns of dispersal from allele frequency data. In Dispersal Ecology; the 42nd symposium of the British Ecological Society. Edited by Bullock JM, Kenward RE, Hails RS. Oxford: Blackwell Science; 2002:89-110.

56. Jost $L: G_{S T}$ and its relatives do not measure differentiation. Mol Ecol 2008, 17:4015-4026

57. Meirmans PG, Hedrick PW: Assessing population structure: $F_{\mathrm{ST}}$ and related measures. Mol Ecol Resour 2011, 11:5-18.

58. Riginos C, Douglas KE, Jin Y, Shanahan DF, Treml EA: Effects of geography and life history traits on genetic differentiation in benthic marine fishes. Ecography 2011, 34:566-575.

59. Pelc RA, Warner RR, Gaines SD: Geographical patterns of genetic structure in marine species with contrasting life histories. J Biogeogr 2009, 36:1881-1890.

60. Bradbury IR, Laurel B, Snelgrove PVR, Bentzen P, Campana SE: Global patterns in marine dispersal estimates: the influence of geography, taxonomic category and life history. Proc R Soc B-Biol Sci 2008, 275:1803-1809.

61. White C, Selkoe KA, Watson J, Siegel DA, Zacherl DC, Toonen RJ: Ocean currents help explain population genetic structure. Proc $R$ Soc B-Bio/ Sci 2010, 277:1685-1694.

62. Sivasundar A, Palumbi SR: Life history, ecology and the biogeography of strong genetic breaks among 15 species of Pacific rockfish, Sebastes. Mar Biol 2011, 157:1433-1452

63. Holsinger KE, Weir BS: Genetics in geographically structured populations: defining, estimating and interpreting F-ST. Nat Rev Genet 2009, 10:639-650.

64. Tietjen JH, Lee JJ: Life-history and feeding habits of marine nematode, Chromadora macrolaimoides Steiner. Oecologia 1973, 12:303-314.

65. Singh R, Ingole B: Life history of a free-living marine nematode Daptonema normandicum reared in laboratory. J Environ Bio/ 2011, 32:147-152.

66. Moens T, Vincx M: Temperature, salinity and food thresholds in two brackish-water bacterivorous nematode species: assessing niches from food absorption and respiration experiments. J Exp Mar Biol Ecol 2000, 243:137-154.

67. Selkoe KA, Watson JR, White C, Ben Horin T, lacchei M, Mitarai S, Siegel DA Gaines SD, Toonen RJ: Taking the chaos out of genetic patchiness: seascape genetics reveals ecological and oceanographic drivers of genetic patterns in three temperate reef species. Mol Ecol 2010, 19:3708-3726.
68. Vranken $\mathrm{G}$, Heip C: Calculation of the intrinsic rate of natural increase, Rm, with Rhabditis marina Bastian 1865 (NEMATODA). Nematologica 1983, 29:468-477.

69. Bongers T, De Goede RGM, Korthals GW, Yeates GW: Proposed changes of c-p classification for nematodes. Russ J Nematol 1995, 3:61-62.

70. Derycke S, Remerie T, Vierstraete A, Backeljau T, Vanfleteren J, Vincx M, Moens T: Mitochondrial DNA variation and cryptic speciation within the free-living marine nematode Pellioditis marina. Mar Ecol Prog Ser 2005, 300:91-103.

71. Derycke S, Backeljau T, Vlaeminck C, Vierstraete A, Vanfleteren J, Vincx M, Moens T: Spatiotemporal analysis of population genetic structure in Geomonhystera disjuncta (Nematoda, Monhysteridae) reveals high levels of molecular diversity. Mar Biol 2007, 151:1799-1812.

72. Derycke S, Backeljau T, Vlaeminck C, Vierstraete A, Vanfleteren J, Vincx M, Moens T: Seasonal dynamics of population genetic structure in cryptic taxa of the Pellioditis marina complex (Nematoda: Rhabditida). Genetica 2006, 128:307-321.

73. Hope WD: Free-Living Marine Nematodes of Genera Pseudocella Filipjev 1927, Thoracostoma Marion 1870 and Deontostoma Filipjev 1916 (Nematoda - Leptosomatidae) from West Coast of North America. Trans Am Microsc Soc 1967, 86:307.

74. Derycke S, De Ley P, De Ley IT, Holovachov O, Rigaux A, Moens T: Linking DNA sequences to morphology: cryptic diversity and population genetic structure in the marine nematode Thoracostoma trachygaster (Nematoda, Leptosomatidae). Zoologica Scripta 2010, 39:276-289.

75. White TA, Stefanni S, Stamford J, Hoelzel AR: Unexpected panmixia in a long-lived, deep-sea fish with well-defined spawning habitat and relatively low fecundity. Mol Ecol 2009, 18:2563-2573.

76. Steyaert M, Herman PMJ, Moens T, Widdows J, Vincx M: Tidal migration of nematodes on an estuarine tidal flat (the Molenplaat, Schelde Estuary, SW Netherlands). Mar Ecol Prog Ser 2001, 224:299-304

77. Slatkin M: Isolation by distance in equilibrium and non equilibirum populations. Evolution 1993, 47:264-279.

78. Bohonak AJ: IBD (isolation by distance): a program for analyses of isolation by distance. J Hered 2002, 93:153-154.

79. Perrin C, Wing SR, Roy MS: Effects of hydrographic barriers on population genetic structure of the sea star Coscinasterias muricata (Echinodermata, Asteroidea) in the New Zealand fiords. Mol Ecol 2004, 13:2183-2195.

80. Ayre DJ, Minchinton TE, Perrin C: Does life history predict past and current connectivity for rocky intertidal invertebrates across a marine biogeographic barrier? Mol Ecol 2009, 18:1887-1903.

81. Derycke S, Remerie T, Backeljau T, Vierstraete A, Vanfleteren J, Vincx M, Moens T: Phylogeography of the Rhabditis (Pellioditis) marina species complex: evidence for long-distance dispersal, and for range expansions and restricted gene flow in the northeast Atlantic. Mol Ecol 2008, 17:3306-3322

82. Bik HM, Thomas WK, Lunt DH, Lambshead PJD: Low endemism, continued deep-shallow interchanges, and evidence for cosmopolitan distributions in free-living marine nematodes (order Enoplida). BMC Evol Biol 2010, 10:389.

83. Bhadury P, Austen MC, Bilton DT, Lambshead PJD, Rogers AD, Smerdon GR: Evaluation of combined morphological and molecular techniques for marine nematode (Terschellingia spp.) identification. Mar Biol 2008, 154:509-518.

84. Maggs CA, Castilho R, Foltz D, Henzler C, Jolly MT, Kelly J, Olsen J, Perez KE, Stam W, Vainola R, et al: Evaluating signatures of glacial refugia for North Atlantic benthic marine taxa. Ecology 2008, 89:S108-S122.

85. Hewitt GM: Some genetic consequences of ice ages, and their role in divergence and speciation. Biol J Linn Soc 1996, 58:247-276.

86. Teske PR, McQuaid CD, Froneman PW, Barker NP: Impacts of marine biogeographic boundaries on phylogeographic patterns of three South African estuarine crustaceans. Mar Ecol Prog Ser 2006, 314:283-293.

87. Avise J: Molecular markers. Evolution: Natural History and; 1994.

88. Wares JP, Gaines SD, Cunningham CW: A comparative study of asymmetric migration events across a marine biogeographic boundary. Evolution 2001, 55:295-306.

89. Dawson MN: Phylogeography in coastal marine animals: a solution from California? J Biogeogr 2001, 28:723-736.

90. Coomans A: Present status and future of nematode systematics. Nematology 2002, 4:573-582.

91. Giere O: Meiobenthology, the microscopic fauna in aquatic sediments. Berlin: Springer-Verlag; 1993. 
92. Vanelslander B, Creach V, Vanormelingen P, Ernst A, Chepurnov VA, Sahan E, Muyzer G, Stal L, Vyverman W, Sabbe K: Ecological differentiation between sympatric pseudocryptic species in the estuarine benthic diatom Navicula phyllepta (Bacillariophyceae). J Phycol 2009, 45:1278-1289.

93. Pfenninger $M$, Schwenk K: Cryptic animal species are homogeneously distributed among taxa and biogeographical regions. BMC Evol Biol 2007, 7:121.

94. Knowlton N: Molecular genetic analyses of species boundaries in the sea. Hydrobiologia 2000, 420:73-90.

95. Lonsdale DJ, Frey MA, Snell TW: The role of chemical signals in copepod reproduction. J Mar Syst 1998, 15:1-12.

96. Stanhope MJ, Connelly MM, Hartwick B: Evolution of a crustacean chemical communication channel - Behavioral and ecological genetic evidence for a habitat-modified, race-specific pheromone. J Chem Ecol 1992, 18:1871-1887.

97. Hay ME: Marine chemical ecology: chemical signals and cues structure marine populations, communities, and ecosystems. Annu Rev Mar Sci 2009, 1:193-212

98. Hockelmann C, Moens T, Juttner F: Odor compounds from cyanobacterial biofilms acting as attractants and repellents for free-living nematodes. Limnol Oceanogr 2004, 49:1809-1819.

99. O'Halloran DM, Fitzpatrick DA, Burnell AM: The chemosensory system of Caenorhabditis elegans and other nematodes. In Chemical Ecology: From Gene to Ecosystem. Volume 16. Wageningen, The Netherlands: Wageningen Ur Frontis Series; 2006:71-88.

100. Grewal PS, Lewis EE, Gaugler R: Response of infective stage parasites (Nematoda: Steinernematidae) to volatile cues from infected hosts. J Chem Ecol 1997, 23:503-515.

101. Bickford D, Lohman DJ, Sodhi NS, Ng PKL, Meier R, Winker K, Ingram KK, Das I: Cryptic species as a window on diversity and conservation. Trends Ecol Evol 2007, 22:148-155

102. Wellborn GA, Broughton RE: Diversification on an ecologically constrained adaptive landscape. Mol Ecol 2008, 17:2927-2936.

103. Derycke S, Fonseca G, Vierstraete A, Vanfleteren J, Vincx M, Moens T: Disentangling taxonomy within the Rhabditis (Pellioditis) marina (Nematoda, Rhabditidae) species complex using molecular and morphological tools. Zool J Linn Soc 2008, 152:1-15.

104. De Oliveira DAS, Decraemer W, Holovachov O, Burr J, De Ley IT, De Ley P, Moens T, Derycke S: An integrative approach to characterize cryptic species in the Thoracostoma trachygaster Hope, 1967 complex (Nematode: Leptosomatidae). Zool J Linn Soc 2012, 164:18-35.

105. Adams BJ: Species concepts and the evolutionary paradigm in modern nematology. J Nematol 1998, 30:1-21.

106. Fonseca G, Derycke S, Moens T: Integrative taxonomy in two free-living nematode species complexes. Biol J Linn Soc 2008, 94:737-753.

107. Sudhaus W, Kiontke K: Comparison of the cryptic nematode species Caenorhabditis brenneri sp $\mathrm{n}$. and C. remanei (Nematoda: Rhabditidae) with the stem species pattern of the Caenorhabditis elegans group. Zootaxa 2007, 1456:45-62.

108. de Leon GPP, Nadler SA: What we don't recognize can hurt us: a plea for awareness about cryptic species. J Parasitol 2010, 96:453-464.

109. Chen G, Hare MP: Cryptic ecological diversification of a planktonic estuarine copepod, Acartia tonsa. Mol Ecol 2008, 17:1451-1468.

110. De Meester N, Derycke S, Bonte D, Moens T: Salinity effects on the coexistence of cryptic species: a case study on marine nematodes. Mar Biol 2011, 158:2717-2726.

111. Hellberg ME, Burton RS, Neigel JE, Palumbi SR: Genetic assessment of connectivity among marine populations. B Mar Sci 2002, 70:273-290

112. Ballard JWO, Melvin RG, Katewa SD, Maas K: Mitochondrial dna variation is associated with measurable differences in life-history traits and mitochondrial metabolism in Drosophila simulans. Evolution 2007, 61:1735-1747.

113. Toth G, Gaspari Z, Jurka J: Microsatellites in different eukaryotic genomes: survey and analysis. Genome Res 2000, 10:967-981.

114. Selkoe KA, Toonen RJ: Microsatellites for ecologists: a practical guide to using and evaluating microsatellite markers. Ecol Lett 2006, 9:615-629.

115. Wielgoss S, Taraschewski H, Meyer A, Wirth T: Population structure of the parasitic nematode Anguillicola crassus, an invader of declining North Atlantic eel stocks. Mol Ecol 2008, 17:3478-3495.

116. Villate L, Esmenjaud D, Van Helden M, Stoeckel S, Plantard O: Genetic signature of amphimixis allows for the detection and fine scale localization of sexual reproduction events in a mainly parthenogenetic nematode. Mol Ecol 2010, 19:856-873.

117. Plantard O, Porte C: Population genetic structure of the sugar beet cyst nematode Heterodera schachtii: a gonochoristic and amphimictic species with highly inbred but weakly differentiated populations. Mol Ecol 2004 13:33-41.

118. Sivasundar A, Hey J: Population genetics of Caenorhabditis elegans: the paradox of low polymorphism in a widespread species. Genetics 2003, 163:147-157.

119. Barriere A, Felix MA: Temporal dynamics and linkage disequilibrium in natural Caenorhabditis elegans populations. Genetics 2007, 176:999-1011.

120. Galindo HM, Pfeiffer-Herbert AS, McManus MA, Chao Y, Chai F, Palumbi SR: Seascape genetics along a steep cline: using genetic patterns to test predictions of marine larval dispersal. Mol Ecol 2010, 19:3692-3707.

121. Galindo HM, Olson DB, Palumbi SR: Seascape genetics: a coupled oceanographic-genetic model predicts population structure of Caribbean corals. Curr Biol 2006, 16:1622-1626.

122. Luikart G, England PR, Tallmon D, Jordan S, Taberlet P: The power and promise of population genomics: from genotyping to genome typing. Nat Rev Genet 2003, 4:981-994.

123. Baird NA, Etter PD, Atwood TS, Currey MC, Shiver AL, Lewis ZA, Selker EU, Cresko WA, Johnson EA: Rapid SNP discovery and genetic mapping using sequenced RAD markers. PLOS One 2008, 3:e3376.

124. Hohenlohe PA, Bassham S, Etter PD, Stiffler N, Johnson EA, Cresko WA: Population genomics of parallel adaptation in threespine stickleback using sequenced RAD tags. PLoS Genet 2010, 6:e1000862.

125. Davey JW, Blaxter ML: RADSeq: next-generation population genetics. Brief Funct Genomics 2010, 9:416-423.

126. Sanford E, Kelly MW: Local adaptation in marine invertebrates. Ann Rev Mar Sci 2011, 3:509-535.

127. Elsworth B, Wasmuth J, Blaxter M: NEMBASE4: the nematode transcriptome resource. Int J Parasitol 2011, 41:881-894.

128. Blaxter M, Kumar S, Kaur G, Koutsovoulos G, Elsworth B: Genomics and transcriptomics across the diversity of the Nematoda. Parasite Immunol 2012, 34:108-120.

129. Sommer RJ, Streit A: Comparative Genetics and Genomics of Nematodes: Genome Structure, Development, and Lifestyle. In Annual Review Genetics. Volume 45. Palo Alto, USA: Annual Review of Genetics; 2011:1-20.

130. Mitreva M, Blaxter ML, Bird DM, McCarter JP: Comparative genomics of nematodes. Trends Genet 2005, 21:573-581.

131. Hillier LW, Miller RD, Baird SE, Chinwalla A, Fulton LA, Koboldt DC, Waterston $\mathrm{RH}$ : Comparison of $\mathrm{C}$. elegans and $\mathrm{C}$. briggsae genome sequences reveals extensive conservation of chromosome organization and synteny. PLOS Biol 2007, 5:1603-1616.

132. Hyman BC, Lewis SC, Tang S, Wu Z: Rampant gene rearrangement and haplotype hypervariation among nematode mitochondrial genomes. Genetica 2011, 139:611-615.

133. Gibson T, Farrugia D, Barrett J, Chitwood DJ, Rowe J, Subbotin S, Dowton $\mathrm{M}$ : The mitochondrial genome of the soybean cyst nematode, Heterodera glycines. Genome 2011, 54:565-574.

134. Armstrong MR, Blok VC, Phillips MS: A multipartite mitochondrial genome in the potato cyst nematode Globodera pallida. Genetics 2000, 154:181-192.

doi:10.1186/1742-9994-10-1

Cite this article as: Derycke et al:: Dispersal and gene flow in free-living marine nematodes. Frontiers in Zoology 2013 10:1. 